\title{
A LONGITUDINAL STUDY ON INCIDENCE AND MORPHOLOGICAL TYPES OF ANAEMIA IN INHABITANTS OF KATIHAR, BIHAR, INDIA
}

\author{
Mohammad Zakiuddin'1, Mansoor Ahmed², Vadiraja $N^{3}$ \\ ${ }^{1}$ Assistant Professor, Department of Physiology, Major S. D. Singh Medical College, Farrukhabad, Uttar Pradesh. \\ ${ }^{2}$ Associate Professor, Department of Community Medicine, MMCRI, Mysore. \\ ${ }_{3}^{3}$ Assistant Professor of Statistics, Department of Community Medicine, MMCRI, Mysore.
}

\section{ABSTRACT}

Available studies on prevalence of Nutritional Anaemia in India showed that $65 \%$ infants and toddlers, $60 \%$ children 1-6 years of age, $80 \%$ adolescent girls and $85 \%$ pregnant women were anaemic. Hence, this study was planned in the subjects visiting Katihar Medical College and Hospital.

\section{AIMS AND OBJECTIVES}

1. To estimate the incidence of anaemia in inhabitants of Katihar.

2. To assess the morphological types of anaemia in different groups of people in this population.

3. To find out the association between anaemia and various socio-demographic factors.

\section{MATERIAL AND METHODS}

The present longitudinal study was carried out between December 2009 and mid August 2011. Using 'Estimation setup technique' with anaemia proportion taken as $40 \%$ with level of significance $5 \%$ and absolute allowable error $7 \%$, the inflated sample size was 197 and was rounded off to 200 . These subjects were selected using convenience sampling. Statistical methods adopted to address the objectives were frequencies, proportions, contingency coefficient and Chi-square test for proportion.

\section{RESULTS}

In the present study, Microcytic, hypochromic anaemia (41.5\%) was the most common type in both males and females. Highest incidence of anaemia in the present series was in the age group of $21-30$ years being $37 \%$. Incidence of anaemia was $62 \%$ in females and 38\% in males. In present study, 130 cases (65\%) were among vegetarians and 90 cases (45\%) were among non-vegetarians; $76 \%$ cases were of low income group and $24 \%$ were middle income group. The commonest presenting symptoms were general weakness and tiredness (84\%).

\section{KEYWORDS}

Longitudinal, Incidence, Anaemia, Morphological.

HOW TO CITE THIS ARTICLE: Zakiuddin M, Ahmed M, Vadiraja N. A longitudinal study on incidence and morphological types of anaemia in inhabitants of Katihar, Bihar, India. J. Evolution Med. Dent. Sci. 2016;5(16):744-748, DOI: 10.14260/jemds/2016/172

\section{INTRODUCTION}

The World Health Organization defines anaemia as hemoglobin or hematocrit level below normal for the age, sex, attitude and physical state of an individual.[1] The World health organization estimates that over 2 billion people are anaemic world-wide. It primarily affects women.[2] The term Anemia (American English) or Anaemia (Common Health English) literally means "Without blood." Anaemia comes from the Greek word anaimia meaning "Lack of blood." Anaemia is also defined as a decrease in total number of red blood cells or less than the normal quantity of hemoglobin in the blood.[3] This results in reduced ability of blood to transfer oxygen to the tissues.

Iron deficiency anaemia is like an iceberg where only the tip is visible. Iron Deficiency Anaemia (IDA) is the most common nutritional deficiency world-wide. It can cause reduced work capacity in adults. ${ }^{[4]}$

Financial or Other, Competing Interest: None

Submission 05-01-2016, Peer Review 30-01-2016,

Acceptance 05-02-2016, Published 23-02-2016.

Corresponding Author:

Dr. Mohammad Zakiuddin,

Assistant Professor, Dept. of Physiology,

Major. S. D. Singh Medical College \& Hospital,

Bewar Road,

Farrukhabad-209601, Uttar Pradesh.

E-mail: mohammadzakiuddin1@gmail.com

DOI: $10.14260 /$ jemds $/ 2016 / 172$
All the age and sex groups are affected by this, but it primarily affects women. The prevalence of anaemia is disproportionately high in developing countries due to illiteracy, lack of knowledge and awareness of balanced diet, inadequate dietary consumption, certain infectious diseases, pregnancy and lactation and poor access to health services. Young people are particularly susceptible because of their rapid growth and associated high iron requirement.

Available studies on prevalence of Nutritional Anaemia in India shows that $65 \%$ infants and toddlers, $60 \%$ children 1 6 years of age, $80 \%$ adolescents girls and $85 \%$ pregnant women were anaemic. About one lakh women die during delivery every year, $40 \%$ of this death is due to anaemia and its complications in India. Incidence of iron deficiency Anaemia is much greater in India than Western countries despite the fact that daily iron intake of Indians is twice that of Westerners.[5] Keeping in view the above facts, a study was planned in the inhabitants of Katihar visiting Katihar Medical College and Hospital to throw light on the incidence and morphological types of Anaemia in this population group and to find out the association between anaemia and various sociodemographic factors.

\section{MATERIAL AND METHODS}

The present study was carried out in the outpatient department and patients admitted in the wards of Katihar Medical College and Hospital, Katihar. 
These cases included males and females in the age group of 15 to 50 years.

Study Design

Longitudinal Study.

\section{Duration of Study}

Between December 2009 and mid-August 2011.

\section{Sample Size}

Using 'Estimation setup technique' with anaemia proportion taken as $40 \%$ with level of significance $5 \%$ and absolute allowable error $7 \%$. The inflated sample size was 197 and was rounded off to 200 . These observations were selected based on convenience sampling technique.

Patients showing marked pallor during clinical examination were selected. Two hundred patients of different age, sex, occupation and socio-economic conditions were selected. Clearance was obtained from the ethical committee of the institution for the study. The subjects were briefed about the study protocol and informed consent was taken. Each subject underwent detailed history taking and thorough clinical assessment.

Patients who had systemic illnesses like hypertension, diabetes mellitus and coronary artery disease were not included in the study. Patients who were diagnosed with malignancies and/or who experienced recent trauma and post-operative/surgical patients were also excluded from this study. Patients were excluded if they had previously ever received a blood transfusion or receipt of iron pills.

\section{Clinical Assessment}

On enrolment a questionnaire including symptoms, medical history and physical examination was completed for all 200 patients; $3 \mathrm{~mL}$ venous blood samples were collected from the cubital fossa using needle syringe in an E.D.T.A Vacutainer and basic hematological parameters were done. Blood tests were done specifically for the study and results were given to the attending physician to enhance patient care.

\section{Laboratory Studies}

A complete blood count was done on electronic cell counter, (Accurex Instrument - CBC - 360- Automatic Hematology Analyser) and R.B.C and Hematocrit values were taken. Leishman's stained thin blood film was studied to determine the blood cell morphology and anaemia. Samples were analysed within 1-2 hours of being drawn.

Hemoglobin estimation was done using Cyanmethemoglobin method employing Drabkin's solution and a spectrophotometer.

\section{Statistical Methods}

Data was entered in Microsoft Excel data sheet and analysis was carried out using R software. Statistical methods adopted to address the objectives were frequencies, proportions, contingency coefficient and Chi square test for proportion. A ' $p$ ' value of $<0.05$ was considered statistically significant.
RESULTS

\begin{tabular}{|c|c|c|}
\hline $\begin{array}{l}\text { TYPES OF } \\
\text { ANAEMIA }\end{array}$ & $\begin{array}{c}\text { NO. } \\
\text { OF } \\
\text { CASES }\end{array}$ & PERCENTAGE \\
\hline $\begin{array}{l}\text { Microcytic Hypochromic } \\
\text { Anaemia }\end{array}$ & 83 & 41.5 \\
\hline $\begin{array}{c}\text { Macrocytic Hypochromic } \\
\text { Anaemia } \\
\end{array}$ & 64 & 32.0 \\
\hline $\begin{array}{c}\text { Macrocytic Normochromic } \\
\text { Anaemia } \\
\end{array}$ & 12 & 6.0 \\
\hline $\begin{array}{c}\text { Normocytic Hypochromic } \\
\text { Anaemia }\end{array}$ & 23 & 11.5 \\
\hline $\begin{array}{l}\text { Normocytic Normochromic } \\
\text { Anaemia }\end{array}$ & 18 & 9.0 \\
\hline
\end{tabular}

\begin{tabular}{|c|c|c|c|}
\hline $\begin{array}{c}\text { Test } \\
\text { Statistic }\end{array}$ & Value & df & $\begin{array}{c}\text { p } \\
\text { value }\end{array}$ \\
\hline $\begin{array}{c}\text { Pearson Chi- } \\
\text { square }\end{array}$ & 99.550 & 4.000 & 0.000 \\
\hline
\end{tabular}

The largest number of cases were of microcytic hypochromic anaemia (41.5\%). Next was normocytic normochromic anaemia (32.0\%) and lowest percentage was macrocytic normochromic anaemia (6\%). This difference in types of anaemia was statistically significant $(\mathrm{p}<0.05)$.

\begin{tabular}{|c|c|c|c|c|}
\hline $\begin{array}{c}\text { AGE } \\
\text { (IN } \\
\text { YEARS) }\end{array}$ & $\begin{array}{c}\text { AGE } \\
\text { GROUP }\end{array}$ & MALE & FEMALE & $\begin{array}{c}\text { TOTAL } \\
\text { NO. OF } \\
\text { CASES }\end{array}$ \\
\hline $15-20$ & $\mathrm{~A}$ & 18 & 28 & 46 \\
\hline $21-30$ & $\mathrm{~B}$ & 36 & 38 & 74 \\
\hline $31-40$ & $\mathrm{C}$ & 18 & 42 & 60 \\
\hline $41-50$ & $\mathrm{D}$ & 4 & 16 & 20 \\
\hline \multicolumn{7}{|c|}{ Table 2: Incidence of Anaemia in different Age and Sex } \\
groups
\end{tabular}

Incidence of anaemia was maximum in males in the age group of 21-30 years, whereas in females it was maximum in age group of 31-40 years.

\begin{tabular}{|c|c|c|c|}
\hline $\begin{array}{c}\text { Test } \\
\text { Statistic }\end{array}$ & Value & df & $\begin{array}{c}\text { P } \\
\text { value }\end{array}$ \\
\hline $\begin{array}{c}\text { Pearson Chi- } \\
\text { square }\end{array}$ & 31.840 & 3.000 & 0.00 \\
\hline
\end{tabular}

Association between age, gender and incidence of anaemia is significant $(\mathrm{p}<0.05)$.

\begin{tabular}{|c|c|c|c|c|}
\hline $\begin{array}{l}\text { RELIGI } \\
\text { ON }\end{array}$ & $\begin{array}{l}\text { VEGETARI } \\
\text { AN }\end{array}$ & $\begin{array}{c}\text { NON- } \\
\text { VEGETARI } \\
\text { AN }\end{array}$ & $\begin{array}{c}\text { NO. } \\
\text { OF } \\
\text { CAS } \\
\text { ES }\end{array}$ & $\begin{array}{c}\text { COMMUNI } \\
\text { TY } \\
\text { PERCENT } \\
\text { AGE }\end{array}$ \\
\hline Hindu & 104 & 36 & 140 & 70 \\
\hline Muslim & 1 & 56 & 57 & 28.5 \\
\hline Others & 1 & 2 & 3 & 1.5 \\
\hline \multicolumn{5}{|c|}{$\begin{array}{l}\text { Table 3: Incidence of Anaemia Related } \\
\text { to Diet in Different Communities }\end{array}$} \\
\hline
\end{tabular}

The incidence of anaemia in the Hindus was maximum (70\%). It was followed by Muslims (28.5\%). Quite a large number of Hindus were vegetarian (74.28\%). 


\begin{tabular}{|c|c|c|c|}
\hline $\begin{array}{l}\text { ECONOMIC } \\
\text { GROUP }\end{array}$ & $\begin{array}{l}\text { SOCIAL } \\
\text { STATUS }\end{array}$ & $\begin{array}{l}\text { NO. OF } \\
\text { CASES }\end{array}$ & $\%$ \\
\hline $\begin{array}{l}\text { Low } \\
\text { Income } \\
\text { Group }\end{array}$ & $\begin{array}{l}\text { Cultivators (Tillers of the } \\
\text { soil). } \\
\text { Labourers and menials } \\
\text { (Non-tillers of soil). }\end{array}$ & 68 & 76 \\
\hline $\begin{array}{l}\text { Middle } \\
\text { Income } \\
\text { Group }\end{array}$ & $\begin{array}{c}\text { Educated middle class. } \\
\text { Example- clerks, } \\
\text { shopkeepers, students, } \\
\text { etc. }\end{array}$ & 48 & 24 \\
\hline $\begin{array}{l}\text { High } \\
\text { Income } \\
\text { Group }\end{array}$ & & None & - \\
\hline \multicolumn{4}{|c|}{$\begin{array}{l}\text { Table 4: Socio-economic Status } \\
\text { amongst the cases of Anaemia }\end{array}$} \\
\hline
\end{tabular}

By far the highest incidence of anaemia was in the patients of low income group (76\%).

In the low income group, labourers and menials had the highest percentage of anaemia (42\%) followed by cultivators (34\%).

\begin{tabular}{|c|c|c|c|c|}
\hline \multirow{2}{*}{$\begin{array}{c}\text { TYPES OF } \\
\text { ANAEMIA }\end{array}$} & $\begin{array}{c}\text { NO. } \\
\text { OF } \\
\text { CASES }\end{array}$ & $\%$ & $\begin{array}{c}\text { NO. } \\
\text { OF } \\
\text { CASES }\end{array}$ & $\%$ \\
\hline $\begin{array}{c}\text { Microcytic } \\
\text { Hypochromic } \\
\text { Anaemia }\end{array}$ & 34 & 41 & 49 & 59 \\
\hline $\begin{array}{c}\text { Macrocytic } \\
\text { Hypochromic } \\
\text { Anaemia }\end{array}$ & 20 & 31.2 & 44 & 68.8 \\
\hline $\begin{array}{c}\text { Normocytic } \\
\text { Hypochromic } \\
\text { Anaemia }\end{array}$ & 09 & 39.1 & 14 & 60.9 \\
\hline $\begin{array}{c}\text { Normocytic } \\
\text { Normochromic } \\
\text { Anaemia }\end{array}$ & 07 & 38.9 & 11 & 61.1 \\
\hline $\begin{array}{c}\text { Macrocytic } \\
\text { Normochromic } \\
\text { Anaemia }\end{array}$ & 04 & 33.3 & 08 & 66.7 \\
\hline \multicolumn{2}{|c|}{$\begin{array}{c}\text { Table 5: Incidence of Morphological } \\
\text { types of Anaemia in different sexes }\end{array}$} \\
\hline
\end{tabular}

According to sex wise incidence, microcytic hypochromic anaemia forms the largest group in both male and female.

Association between the morphological types of Anaemia and Gender is insignificant (p.0.05).

\begin{tabular}{|c|c|c|c|c|}
\hline $\begin{array}{c}\text { Test } \\
\text { Statistic }\end{array}$ & Value & df & $\begin{array}{c}\text { P } \\
\text { value }\end{array}$ & $\begin{array}{c}\text { Coefficient of } \\
\text { Contingency }\end{array}$ \\
\hline $\begin{array}{c}\text { Pearson } \\
\text { Chi-square }\end{array}$ & 8.025 & 4.000 & 0.091 & 0.20 \\
\hline
\end{tabular}

\begin{tabular}{|c|c|c|c|}
\hline $\begin{array}{c}\text { GRADES } \\
\text { OF } \\
\text { ANAEMI } \\
\text { A }\end{array}$ & $\begin{array}{c}\text { HEMOGLOBIN } \\
\text { CONCENTRATI } \\
\text { ON (g/dL) }\end{array}$ & $\begin{array}{c}\text { NO. } \\
\text { OF CASES }\end{array}$ & $\%$ \\
\hline Mild & $10-11.9$ & 66 & 33 \\
\hline Moderate & $7-9.9$ & 104 & 52 \\
\hline Severe & $<7.0$ & 30 & 15 \\
\hline \multicolumn{3}{|c|}{$\begin{array}{c}\text { Table 6: Grading of Anaemia as } \\
\text { per Haemoglobin concentration }\end{array}$} \\
\hline
\end{tabular}

Maximum cases were having haemoglobin between 7$9.9 \mathrm{~g} / \mathrm{dL}$ that falls in moderate anaemia category (52\%) followed by mild category (33\%). This difference was statistically significant $(\mathrm{p}<0.05)$.

\begin{tabular}{|c|c|c|c|}
\hline $\begin{array}{c}\text { Test } \\
\text { Statistic }\end{array}$ & Value & df & $\begin{array}{c}\text { P } \\
\text { Value }\end{array}$ \\
\hline $\begin{array}{c}\text { Pearson } \\
\text { Chi-square }\end{array}$ & 41.080 & 2.000 & 0.000 \\
\hline
\end{tabular}

\begin{tabular}{|c|c|c|c|}
\hline $\begin{array}{c}\text { AGE } \\
\text { (IN YEARS) }\end{array}$ & GROUP & $\begin{array}{c}\text { NO. OF } \\
\text { CASES }\end{array}$ & PERCENTAGE \\
\hline $15-20$ & $\mathrm{~A}$ & 16 & 19.3 \\
\hline $21-30$ & $\mathrm{~B}$ & 32 & 38.5 \\
\hline $31-40$ & $\mathrm{C}$ & 21 & 25.3 \\
\hline $41-50$ & $\mathrm{D}$ & 14 & 16.9 \\
\hline \multicolumn{3}{|c|}{ Table 7: Incidence of Microcytic } \\
Hypochromic Anaemia in different age groups \\
\hline
\end{tabular}

Maximum cases of microcytic hypochromic anaemia were found in age group B (21-30 years) followed by age group C (31-40 years). The difference in age occurrence of this type of anaemia was statistically significant $(\mathrm{p}<0.05)$.

\begin{tabular}{|c|c|c|c|c|}
\hline $\begin{array}{c}\text { Test } \\
\text { Statisti } \\
\text { c }\end{array}$ & Value & df & $\begin{array}{c}\text { P } \\
\text { value }\end{array}$ & $\begin{array}{c}\text { Coefficient } \\
\text { of } \\
\text { Contingency }\end{array}$ \\
\hline $\begin{array}{c}\text { Pearson } \\
\text { Chi- } \\
\text { square }\end{array}$ & 249.000 & 9.000 & 0.000 & 0.866 \\
\hline
\end{tabular}

\begin{tabular}{|c|c|c|c|}
\hline AGE (IN YEARS) & GROUP & $\begin{array}{c}\text { NO. OF } \\
\text { CASES }\end{array}$ & \% \\
\hline $15-20$ & A & 19 & 29.7 \\
\hline $21-30$ & B & 26 & 40.6 \\
\hline $31-40$ & C & 10 & 15.7 \\
\hline $41-50$ & D & 9 & 14.0 \\
\hline Table 8: Incidence of Macrocytic Hypochromic \\
Anaemia in different age groups \\
\hline
\end{tabular}

Maximum number of cases were found in age group B (21-30 years) followed by age group A (15-20 years). This difference in age groups was statistically significant $(p<0.05)$.

\begin{tabular}{|c|c|c|c|c|}
\hline $\begin{array}{c}\text { Test } \\
\text { Statistic }\end{array}$ & Value & df & $\begin{array}{c}\mathbf{P} \\
\text { value }\end{array}$ & $\begin{array}{c}\text { Coefficient of } \\
\text { Contingency }\end{array}$ \\
\hline $\begin{array}{c}\text { Pearson } \\
\text { Chi- } \\
\text { square }\end{array}$ & $\begin{array}{c}192.00 \\
0\end{array}$ & 9.000 & 0.000 & 0.866 \\
\hline
\end{tabular}

\begin{tabular}{|c|c|c|c|}
\hline $\begin{array}{c}\text { AGE } \\
\text { (IN YEARS) }\end{array}$ & GROUP & $\begin{array}{c}\text { NO. } \\
\text { OF CASES }\end{array}$ & $\%$ \\
\hline $15-20$ & $\mathrm{~A}$ & 2 & 11.1 \\
\hline $21-30$ & $\mathrm{~B}$ & 8 & 44.4 \\
\hline $31-40$ & $\mathrm{C}$ & 5 & 27.8 \\
\hline $41-50$ & $\mathrm{D}$ & 3 & 16.7 \\
\hline \multicolumn{3}{|c|}{ Table 9: Incidence of Normocytic } \\
Normochromic Anaemia in different age groups \\
\hline
\end{tabular}

Incidence was maximum in age group C (31-40 years). Age group B (21-30 years) have slightly lower than Group C, whereas Group D has lowest number of cases. This age difference was significant statistically $(\mathrm{p}<0.05)$. 


\begin{tabular}{|c|c|c|c|c|}
\hline Test Statistic & Value & df & P value & $\begin{array}{c}\text { Coefficient } \\
\text { of } \\
\text { Contingency }\end{array}$ \\
\hline Pearson Chi-square & 54.000 & 9.000 & 0.000 & 0.866 \\
\hline
\end{tabular}

\begin{tabular}{|c|c|c|c|}
\hline $\begin{array}{c}\text { AGE } \\
\text { (IN YEARS) }\end{array}$ & GROUP & $\begin{array}{c}\text { NO. } \\
\text { OF CASES }\end{array}$ & $\%$ \\
\hline $15-20$ & A & 1 & 8.3 \\
\hline $21-30$ & B & 2 & 16.7 \\
\hline $31-40$ & $\mathrm{C}$ & 7 & 58.3 \\
\hline $41-50$ & $\mathrm{D}$ & 2 & 16.7 \\
\hline
\end{tabular}

Maximum number of cases were found in age group $\mathrm{C}$ (31-40 years) and this difference in age occurrence was statistically significant $(\mathrm{p}<0.05)$.

\begin{tabular}{|c|c|c|c|c|}
\hline $\begin{array}{c}\text { Test } \\
\text { Statistic }\end{array}$ & Value & df & $\begin{array}{c}\mathbf{P} \\
\text { value }\end{array}$ & $\begin{array}{c}\text { Coefficient of } \\
\text { Contingency }\end{array}$ \\
\hline $\begin{array}{c}\text { Pearson } \\
\text { Chi- } \\
\text { square }\end{array}$ & 36.000 & 9.000 & 0.000 & 0.866 \\
\hline
\end{tabular}

\begin{tabular}{|c|c|c|c|}
\hline $\begin{array}{c}\text { AGE } \\
\text { (IN YEARS) }\end{array}$ & GROUP & $\begin{array}{c}\text { NO. } \\
\text { OF CASES }\end{array}$ & \% \\
\hline $15-20$ & $\mathrm{~A}$ & 2 & 8.7 \\
\hline $21-30$ & $\mathrm{~B}$ & 9 & 39.1 \\
\hline $31-40$ & $\mathrm{C}$ & 9 & 39.1 \\
\hline $41-50$ & $\mathrm{D}$ & 3 & 13.1 \\
\hline \multicolumn{2}{|c|}{ Table 11: Incidence of Normocytic } \\
Hypochromic Anaemia in different age groups \\
\hline
\end{tabular}

Incidence of normocytic hypochromic anaemia was similar in age group B (21-30 years) and age group C (31-40 years).

\begin{tabular}{|c|c|c|c|c|}
\hline $\begin{array}{c}\text { Test } \\
\text { Statistic }\end{array}$ & Value & df & $\begin{array}{c}\mathbf{P} \\
\text { value }\end{array}$ & $\begin{array}{c}\text { Coefficient } \\
\text { of } \\
\text { Contingency }\end{array}$ \\
\hline $\begin{array}{c}\text { Pearson Chi- } \\
\text { square }\end{array}$ & 69.000 & 9 & 0.000 & 0.866 \\
\hline
\end{tabular}

\begin{tabular}{|c|c|c|}
\hline SYMPTOMS & NO. OF CASES & $\%$ \\
\hline Weakness & \multirow[b]{2}{*}{168} & \multirow[b]{2}{*}{84} \\
\hline Tiredness & & \\
\hline Pallor & 74 & 37 \\
\hline Fever & 87 & 43.5 \\
\hline Giddiness & 86 & 43 \\
\hline Headache & 38 & 19 \\
\hline Loss of Appetite & 28 & 14 \\
\hline Palpitation & 86 & 43 \\
\hline $\begin{array}{c}\text { Breathlessness on } \\
\text { exertion }\end{array}$ & 30 & 15 \\
\hline Fatigability & 56 & 28 \\
\hline $\begin{array}{c}\text { Numbness and } \\
\text { tingling sensation }\end{array}$ & 8 & 4 \\
\hline Bleeding from gums & 6 & 3 \\
\hline Epistasis & 1 & 0.5 \\
\hline Purpuric Spots & 1 & 0.5 \\
\hline $\begin{array}{c}\text { Dimness of Night } \\
\text { Vision }\end{array}$ & 34 & 17 \\
\hline $\begin{array}{r}\text { Table 12 } \\
\text { Sympto }\end{array}$ & $\begin{array}{l}\text { dence of Prese } \\
\text { Cases of Anae }\end{array}$ & \\
\hline
\end{tabular}

\section{DISCUSSION}

Recently, the World Health Organisation estimated that anaemia affects one quarter of the world's population and is concentrated within pre-school children and women.[6]

In this study, incidence of anaemia was $62 \%$ in females and $38 \%$ in males. This scenario is probably because of the fact that females usually bear the brunt of household physical strain, low dietary intake, poor iron and folic acid intake with an increased risk of infection. In some societies, mostly the males and children are served food first and the lady has to satisfy herself with the remains of the poor quality food, leading to serious malnutrition. ${ }^{[8]}$

In females, incidence of anaemia was maximum in age group of 21-40 years. This is perhaps due to blood loss during menstruation and additional demands of pregnancy. Other Indian studies have also shown high prevalence of iron deficiency anaemia among young women.[7,8] The high prevalence of iron deficiency anaemia among women in childbearing age has important public health implications. It is estimated that anaemia accounts for $12.8 \%$ of maternal mortality in Asia.[9] Iron requirements are greater in pregnancy and iron deficiency is associated with maternal death, preterm delivery and low birth-weight.[10,11]

Apart from this macrocytic normochromic type of blood picture was found in $66.7 \%$ females and $33.3 \%$ males. This type of blood picture is seen in megaloblastic anaemia due to deficiency of $\mathrm{B}_{12}$ or folic acid or both, which are common in females because majority of females are vegetarian compared to male.

In present study, amongst 200 cases of anaemia 130 cases $(65 \%)$ cases were vegetarians and 90 cases $(45 \%)$ were non-vegetarians. Non-vegetarians could afford meat or fish only once or twice a month and that too in a very small quantity. Considering this poor and unbalanced diet in the observed cases, malnutrition had a definite role in causation of anaemia.

Majority of the patients in present study were very poor (Low income group) and could afford only two meals a day. The vegetarian meal consists of cereals (e.g. Rice, wheat, etc.), dal, potato, some green vegetables, etc. The only animal protein available was milk and that too many could not afford. Milk was omitted by many due to gastrointestinal upset and its high cost. Fruits were rarely taken.

It has been observed in other studies in India that only $28 \%$ of women consume meat, fish or eggs on a weekly basis. ${ }^{[12]}$ and the iron bioavailability of the vegetarian diet is very poor.[10,13]

\section{SUMMARY AND CONCLUSION}

The present work was done to evaluate the incidence and morphological types of anaemia in different groups of people in the population of Katihar, Bihar.

In this study, incidence of anaemia was $62 \%$ in females and $38 \%$ in males. Incidence of anaemia was maximum in the age group of 31-40 years in females, whereas in males incidence was maximum in age group of 21-30 years. About $15 \%$ cases were found to be having hemoglobin concentration below $7.0 \mathrm{~g} / \mathrm{dL}$, which falls under category of severe anaemia. Anaemia was mostly found in people of low income group consisting of cultivators, labourers, etc. Common presenting symptoms of these patients were weakness, tiredness, anorexia, easy fatigability, giddiness, breathlessness on 
exertion and palpitation. A very important associated factor was malnutrition and dietary deficiency. Microcytic hypochromic anaemia was the commonest type of anaemia (41.5\%) found in this series.

It has been observed in this study that anaemia has strong relation with age, sex, religion, social status and dietary habits. We conclude that anaemia is a significant health problem, particularly of women. It needs new programme strategies, particularly those that improve the overall nutrition status of women. This will require tailored programs across the socioeconomic groups. Problem of anaemia is not difficult to treat, but effort must be made to educate women and enhance their level of economic status. The approach of treating anaemia should be an early approach, so that it should not progress to severe stage. Hence, it is important to know the aetiology of anaemia and treat it accordingly. These findings also suggest that intervention for anaemia should be directed at all members of the community. There is a need to give special attention to improve the hemoglobin status of pregnant women through dietary modification along with preventive supplementation and nutrition education. All of these efforts would help to ensure safe motherhood and to achieve the relevant targets of the Millennium Development Goals. It is hoped that this study will stimulate further works in this field and help to reduce mortality and morbidity due to anaemia by early diagnosis and effective corrective measures.

\section{BIBLIOGRAPHY}

1. Blanc B, Finch CA, Hallberg L. Nutritional anaemias. Report of a WHO Scientific Group. WHO Tech Rep Ser 1968;405:14.

2. Toteja G, Singh P. Micronutrient deficiency disorders in 16 districts of India. Report of an ICMR task force study, District Nutrition Project Part-1: 2001.
3. Definition of anaemia. Available from: http://www.medicinenet.com [Last accessed on 2011 Sept 21].

4. Anthea Maton, Jean Hopkins, Charles William McLaughlin, et al. (1993). Human Biology and Health. Englewood Cliffs, New Jersey, USA, Prentice Hall. ISBN-0-13-981176-1.

5. Linda S Costanzo (2007), Hagerstwon, MD. Physiology: Lippincott Williams and Wilkins. ISBN-0-7817-7311-3.

6. Luby SP, et al. Using clinical signs to diagnose anaemia in African children. Bulletin of the World Health Organization 1995;73:477-482.

7. Memon KC, Skeaff SA, et al. Concurrent micronutrient deficiencies prevalence in non-pregnant rural and tribal women from Central India. Nutrition-2011; Vol 27, No 4: 496-502.

8. Thankachan P, Muthayya S, et al. Analysis of etiology of anaemia and iron deficiency in young women of low socioeconomic status: Bangalore, India-Food and nutrition bulletin 2007; Vol 28, No 3: 328-336.

9. Khan KS, Wojdyla D, et al. WHO analysis of causes of maternal death- a systematic review 2006; Vol 367, No 9516:1066-1074.

10. Kalaivani K- Prevalence and consequences of anaemia in Pregnancy. Indian Journal of Medical Research 2009; Vol 130, No 5: 627-633.

11. Allen LH. Anaemia and iron deficiency-The American Journal of Clinical Nutrition 2000; Vol 71, No 5: s1280s1284.

12. Arnold F, Parasuraman S, et al. Nutrition in India: National Family Health Survey (NFHS-3) 2009.

http://www.rchiips.org/nfhs/nutrition report for website.pdf.

13. Shridhar K, Dhillon PK, et al. Nutritional profile of Indian vegetarian diets-the Indian migration study 2014 Nutrition Journal, vol 13, article 55. 